same response may be applied to $G$ protein-linked receptors, particularly those without introns. It is postulated that many of the genes encoding the $G$ protein-linked receptor family evolved from a single precursor gene (possibly an opsin gene) that lost its introns approximately 1 billion years ago $^{23}$. Since then, gene duplication events have resulted in many related genes. These intronless genes are so small that they are more likely to be functional, when duplicated, than large intron-containing genes and have, therefore, diverged into a large, related family of functional receptors. These events would, therefore, allow an increase in the diversity of receptors available and correspondingly in the level of complexity possible, particularly in the brain, conferring an evolutionary advantage. So, why have $\mathrm{G}$ protein-linked $5-\mathrm{HT}_{1}$-like receptors diversified so extensively? Answer: because they can!

MARGARET S. BEER, DEREK N. MIDDLEMISS AND GEORGE MCALLISTER

Merck Sharp and Dohme Laboratories, Neuroscience Research Centre, Terlings Park, Eastwick Road, Harlow, Essex, UK CM20 2QR

\section{References}

1 Kobilka, B. K. et al. (1987) Nature 329, 75-79

2 Fargin, A. et al. (1988) Nature 335, 358-360

3 Julius, D., MacDermott, A. B., Axel, R. and Jessell, T. M. (1988) Science 241, 558-564

4 Hoyer, D. and Middlemiss, D. N. (1989) Trends Pharmacol. Sci. 10, 130-132

5 Hambli.., M. W. and Metcalf, M. A. (1991) Mfol. Pharmacol. 40, 143-148

6 Maenhaut, C. et al. (1991) Biochem. Biophys. Res. Commun. 180, 1460-1468

7 Voight, M. M., Laurie, D. J., Seeburg, P. H. and Bach, A. (1991) EMBO /. 10, 4017-4023

8 Weinshank, R. L., Zgombick, J. M., Macchi, M. J., Branchek, T. A. and Hartig, P. R. (1992) Proc. Natl Acad. Sci. USA 89, 3630-3634

9 Hartig, P. R., Branchek, T. A. and Weinshank, R. L. (1992) Trends Pharmacol. Sci. 13, 152-159

10 Oksenberg, D. et al. (1992) Nature 360, 161-163

11 Heuring, R. E. and Peroutka, 5. J. (1987) I. Neurosci. 7, 894-903

12 Waeber, C., Schoeffter, P., Palacios, J. M. and Hoyer, D. (1988) NaunynSchmied. Arch. Pharmacol. 337, 595-601

13 Beer, M. S., Stanton, J. A., Becan, Y., Chauhan, N. S. and Middlemiss, D. N. (1992) Eur. J. Pharmacol. 213, 193-197

14 Sumner, M. J. and Humphrey, P. P. A. (1989) Br. I. Pharmacol. 98, 29-31

15 Leonhardt, S., Herrick-Davis, K. and
Titeler, M. (1989) I. Neurochem. 53, $465-471$

16 McAllister, G. et al. (1992) Proc. Natl Acad. Sci. USA 89, 5517-5521

17 Levy, F. O., Gudermann, T., Birnbaumer, M., Kaumann, A. J. and Birnbaumer, L. (1992) FEBS Lett. 296. 201-206

18 Zgombick, J. M. et al. (1992) Mol. Pharmacol. 42, 180-185

19 Levy, F. O. et al. (1992) J. Biol. Chem. 267.
$7553-7562$

20 Beer, M. S., Stanton, J. A., Hawkins, L. M. and Middlemiss, D. N. (1993) Eur. I. Pharmacol. (in press)

21 Amlaiky, N., Ramboz, S., Boschert, U., Plassat, J-L. and Hen, R. (1992) I. Biol. Chem. 267, 19761-19764

22 Adham, N. et al. (1993) Proc. Natl Acad. Sci. USA 90, 408-412

23 Doolittle, R. (1986) in Of Urfs and Orfs, University Science Books, pp. 37-47

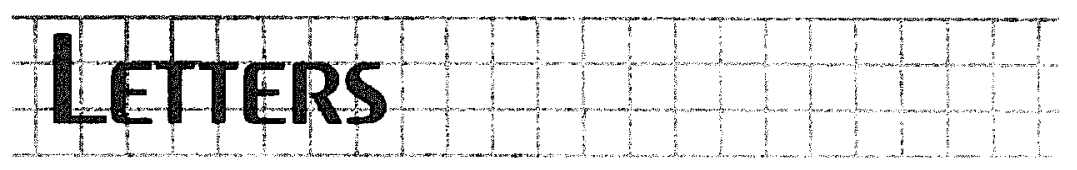

Is the relaxin system a target for drug development?

\title{
Cardiac effects of relaxin
}

In a recent issue of TiPS, Kakouris and colleagues ${ }^{1}$ reported that human relaxin gene 2 product causes concentration-dependent positive chronotropic and inotropic effects by acting directly on specific receptors in the rat isolated atria. On the basis of these findings, together with the demonstration of specific highaffinity binding sites for relaxin in the rat heart ${ }^{2}$ as well as of the increase in serum relaxin concentrations during the first trimester of human pregnancy ${ }^{3}$, Kakouris and colleagues ${ }^{l}$ imply that relaxin may be responsible for the elevation of cardiac output during pregnancy. The authors also suggest ${ }^{1}$ that 'the relaxin system (receptors, degradation mechanisms, cell signalling, etc.) could be a novel target for the development of potential inotropic agents'.

We believe that these assertions are, to say the least, premature, for several reasons. First, the highly preferential venodilator effect of relaxin leading to decreased venous blood velocity ${ }^{4}$ will tend to reduce circulating blood volume, venous return and, consequently, cardiac output. Secondly, the ensuing tachycardia with relaxin might partly offset the potential advantage of its cardiotonic action. Thirdly, it should be noted that while the binding of ${ }^{32} \mathrm{P}$ relaxin... was seen clearly in the heart atria, ...the ventricles did not show detectable binding ${ }^{2}$ (see also Fig. 1 in Ref. 2). Indeed, our recent observations dealing with the cardiac effects of 5-HT have established that the increase in contractility induced by this amine in the atrium of both pigs ${ }^{5,6}$ and humans ${ }^{7}$ is not observed in the ventricular myocardium.

We therefore suggest that, although relaxin may elevate curdiac output by increasing heart rate, it is unlikely that relaxin would do so via a positive inotropic effect on the ventricular myocardium. This signifies that the approach of developing potential inotropic agents via the relaxin system will probably not be very rewarding.

\section{References}

1 Kakouris, H., Eddie, L. W. and Summers, R. J. (1993) Trends Pharmacol. Sci. 14, 4-6

2 Osheroff, P. L., Cronin, M. J. and Lofgren, J. A. (1992) Pror. Natl Acad. S.i. USA 89, 2384-2388

3 Bell, R. J. et al. (1987) Obstet. Gynecol. 69. 585-589

4 Bigazzi, M., Del Mese, A., Petrussi, F., Casali, R. and Novelli, G. P. (1986) Acta Endocrinol. 112, 296-299

5 Saxena, P. R., Villalún, C. M. Dhasmana, K. M. and Verdouw, P. D. (1992) Naunyn-Schmied. Arch. Pharmacol. 346, 629-636

6 Schoemaker, R. G., Du, X. Y., Bax, W. A and Saxena, P. R. (1992) NaunynSchmied. Arch. Pharmacol. 346, 486-489

7 Schoemaker, R. G., Du, X. Y., Bax, W. A and Saxena, P. R. (1993) Eur. 1. Pharmacol. 239, 103-105

PRAMOD R. SAXENA, WILLEM A. BAX, XIAO Y. DU AND REGIEN G. SCHOEMAKER

Department of Pharmacology and Cardiovascular Research Institute 'COEUR', Faculty of Mcdicine and Hcalth Sriences, Erasmus University Rotterdam, PB 1738, $3000 \mathrm{DR}$ Rotterdan, The Netherlands. 